\title{
Zastupljenost nacionalnih manjina u hrvatskoj javnoj upravi: ocjena uspješnosti posebnih mjera zapošljavanja
}

\author{
DOI: https://doi.org/10.11567/met.33.2.3 \\ UDK: 331.5:35]-054.57(497.5) \\ Pregledni rad \\ Primljeno: 12.10.2017. \\ Prihvaćeno: 11.12.2017.
}

\author{
Tijana Vukojičić Tomić
}

Pravni fakultet Sveučilišta u Zagrebu, Zagreb

tijana.vukojicic@pravo.hr

\begin{abstract}
SAŽETAK
U radu se analizira postojeći model zapošljavanja nacionalnih manjina $u$ hrvatskoj javnoj upravi. Nacionalne manjine zapošljavaju se primjenom posebnih mjera zapošljavanja koje se razlikuju od uobičajenih metoda odabira i zapošljavanja javnih službenika. One se donose radi postizanja stvarne jednakosti nacionalnih manjina i propisuju se kao pravo na zastupljenost. Mogu se okarakterizirati kao ciljevi zapošljavanja i predstavljaju brojčano iskazane ciljeve i indikatore željene razine zastupljenosti pripadnika manjinskih skupina. U Hrvatskoj se posebne mjere zapošljavanja nacionalnih manjina donose već početkom devedesetih godina 20. stoljeća, ali se tek početkom 21. stoljeća, unapređenjem zakonskih rješenja, može govoriti o stvaranju pretpostavki uspostavljanju sustava zapošljavanja nacionalnih manjina u javnoj upravi. Kako bi se provjerila adekvatnost trenutačnog modela zapošljavanja nacionalnih manjina u hrvatskoj javnoj upravi, u radu se analiziraju podaci o zapošljavanju u tijelima državne uprave i upravnim tijelima jedinica lokalne i područne (regionalne) samouprave. Iznose se temeljni problemi u provedbi posebnih oblika zapošljavanja nacionalnih manjina u javnoj upravi te se razmatraju postojeći model i potreba njegove promjene, odnosno uvođenja dodatnih mjera.
\end{abstract}

KLJUČNE RIJEČI: nacionalne manjine, zapošljavanje, posebne mjere zapošljavanja, javna uprava, Hrvatska

\section{UVOD}

U vrijeme povećane složenosti nacionalne strukture suvremenih društava pitanje zapošljavanja nacionalnih manjina sve više dobiva na važnosti. Takva situacija dovodi do razvoja nacionalnih politika i čitavog niza zakonskih mjera kojima se nastoji strukturom ljudskih potencijala u javnoj upravi odraziti složenost društvene okoline. Također, posebni oblici zapošljavanja 
manjina razvijaju se u okviru međunarodnoga antidiskriminacijskog prava još od sredine šezdesetih godina 20. stoljeća.

Zapošljavanje manjina podrazumijeva posebne oblike zapošljavanja koji se razlikuju od uobičajenih metoda odabira i zapošljavanja ljudi u organizaciji. Posebne mjere zapošljavanja donekle se razvijaju i u okviru privatnog sektora, ali su posebno naglašene u javnoj upravi. Razlog tome, prije svega, proizlazi iz shvaćanja upravne službe kao društvene funkcije jer se u okviru upravnih organizacija obavljaju poslovi koji su korisni i potrebni društvenoj zajednici, odnosno javni poslovi.

Posebne mjere zapošljavanja donose se radi postizanja stvarne jednakosti nacionalnih manjina i u načelu su privremene naravi jer trebaju trajati onoliko dugo koliko je potrebno da se postigne njihov cilj. Uz otklanjanje ili ublažavanje posljedica diskriminacije, cilj njihova donošenja može biti i integracija manjina u organizaciji, pa čak i postizanje boljih rezultata rada organizacije putem upravljanja različitošću. Većina europskih zemalja propisuje barem jednu mjeru preferencijalnog zapošljavanja nacionalnih manjina, a vrlo se često upotrebljava kombinacija više mjera. Najčešće je riječ o mjerama poput ciljeva zapošljavanja, kvota, poticanja zapošljavanja, promidžbenih kampanja, ciljanog oglašavanja i sl.

U Hrvatskoj se posebne mjere zapošljavanja nacionalnih manjina donose već početkom devedesetih godina 20. stoljeća, ali se ne provode u praksi. Tek početkom 21. stoljeća stvaraju se pretpostavke uspostavljanja sustava zapošljavanja nacionalnih manjina. Svrha ovog rada jest provjeriti adekvatnost trenutačnog modela zapošljavanja nacionalnih manjina u hrvatskoj javnoj upravi. Analizom su se nastojali provjeriti stvarni učinci pozitivnog zakonodavstva. U prvom dijelu rada iznose se konceptualizacije pojma nacionalna manjina te se ukratko analiziraju promjene udjela osoba koje se izjašnjavaju kao nacionalne manjine u Hrvatskoj. Nakon toga se objašnjava značenje posebnih mjera zapošljavanja nacionalnih manjina i iznosi njihov razvoj u hrvatskom zakonodavstvu. Na kraju se analiziraju podaci o zapošljavanju nacionalnih manjina u tijelima državne uprave i upravnim tijelima jedinica lokalne i područne (regionalne) samouprave za razdoblje od 2006. do 2015. Na temelju toga razmatraju se adekvatnost postojećeg modela i potreba njegove promjene, tj. uvođenja novih/dodatnih mjera zapošljavanja koje trebaju pridonijeti ravnomjernoj zastupljenosti nacionalnih manjina $\mathrm{u}$ odnosu na njihov udio u stanovništvu. 


\section{NACIONALNE MANJINE U REPUBLICI HRVATSKOJ}

Mnogobrojne su teorijske definicije pojma manjina ili manjinskih skupina. ${ }^{1}$ No kako se njima ne mogu obuhvatiti svi oblici i sva obilježja različitosti čiji se krug s vremenom širi, u literaturi se uglavnom navode karakteristična obilježja manjinskih skupina. ${ }^{2}$ Dio autora, posebno u okviru sve inflatornijeg pristupa multikulturalizma, radije govori o identitetnim različitostima pojedinaca i društvenih skupina. Pojmom identiteta obuhvaćene su naslijeđena i izabrana odnosno stečena (achieved) obilježja koja ljude svrstavaju u posebne grupe, bilo da ih važnima smatraju članovi grupe ili njihova okolina (Mesić, 2006: 37). Takvo poimanje različitosti kao temelj za razumijevanje manjinskog statusa uključuje svjesnost i izbor kao socijalno konstruirane grupne identitete (npr. vjera ili obrazovanje) nasuprot isticanju isključivo pripisanih ili bioloških obilježja (npr. rasa ili spol). Zbog toga se prikladnijim i obuhvatnijim čine sljedeća karakteristična obilježja manjinskih skupina:

1. Manjinska skupina ima istaknuta obilježja, poput rasne ili nacionalne pripadnosti, pripadnosti pojedinoj socijalnoj klasi, seksualne orijentacije, dobi ili vjere, koja je čine različitom od dominantne skupine u društvu.

2. Pripadnici manjinske skupine trpe posljedice diskriminatornog ili nepravednog postupanja od dominantne skupine u društvu.

3. Pripadnost skupini najčešće je pripisana, ali i stečena pripadnost može biti temelj za identifikaciju pojedinaca kao članova skupine.

4. Pripadnici manjinske skupine gaje čvrst osjećaj grupne solidarnosti koja proizlazi iz zajedničke kulturne stečevine i povijesnih iskustava s predrasudama i diskriminacijom (Andersen i Taylor, 2008: 275).

Jednu od istaknutijih i često upotrebljavanih definicija prema kojoj su manjine "grupe ljudi koji su zbog svojih fizičkih ili kulturnih osobina izdvojeni od ostalih u društvu u kome žive različitim i nejednakim postupanjem prema njima, i koji se zato smatraju predmetom kolektivne diskriminacije « postavio je Wirth (1945: 347). Wirth posebno ističe da postojanje neke manjine podrazumijeva postojanje odgovarajuće skupine u društvu koja uživa viši društveni status i povlastice te da su manjine isključene iz punog sudjelovanja u životu društva.

2 Wagley i Harris (1958, prema: Henderson i Olasiji, 1995: 5-6) identificiraju pet takvih obilježja: povijesno nejednak položaj odnosno izloženost nepravednom postupanju članova manjinske skupine, uočljive fizičke ili kulturne karakteristike koje ih razlikuju od ostatka stanovništva, pripadnost grupi koja se ne temelji na svjesnoj odluci pojedinca, naglašena pojava sklapanja braka među članovima grupe i postojanje svijesti o manjinskom statusu u odnosu na druge. Iako se ta grupa obilježja u literaturi najčešće citira, uz nju se vežu barem dva problema koja proizlaze iz činjenice da se uzimaju u obzir samo neke grupe različitosti koje autore upućuju na isticanje pripisivanih (ascribed) obilježja bez svjesne odluke pojedinca i unutargrupno sklapanje braka. 
U pogledu nacionalnih manjina važno je istaknuti kako ne postoji jedinstvena, općeprihvaćena definicija tog pojma (Arlović, 2015: 76-77). Stoga nije rijetkost da se u znanstvenoj i stručnoj literaturi upotrebljavaju različiti izrazi (npr. etničke, nacionalne manjine, rasne, jezične manjine) kao sinonimi. Pojedini autori, pa i neke međunarodne institucije, ističu karakteristična obilježja odnosno elemente po kojima je nacionalne manjine moguće razlikovati od većinskog stanovništva. ${ }^{3}$

U hrvatskom zakonodavstvu nacionalna manjina jest »skupina hrvatskih državljana čiji pripadnici su tradicionalno nastanjeni na teritoriju Republike Hrvatske, a njeni članovi imaju etnička, jezična, kulturna i/ili vjerska obilježja različita od drugih građana i vodi ih želja za očuvanjem tih obilježja «. ${ }^{4}$ Pripadnicima nacionalnih manjina Ustavom se jamči ravnopravnost i određuje da se ravnopravnost i zaštita njihovih prava uređuju ustavnim zakonom koji se donosi po postupku za donošenje organskih zakona. Čl. 83. st. 1. određuje da se zakoni (organski zakoni) kojima se uređuju prava nacionalnih manjina donose dvotrećinskom većinom glasova svih zastupnika. Time su, prema Smerdelu (2013: 300), jamstva prava nacionalnih manjina institucionalno ojačana jer zahtjev za dvotrećinskom većinom glasova svih zastupnika daje zakonodavstvu o nacionalnim pravima jaču pravnu snagu nego čak i ostalim organskim zakonima, pa se ti zakoni po svojoj pravnoj snazi nalaze između Ustava i ostalih organskih zakona. ${ }^{5}$

Prema Preporuci 1201. Vijeća Europe (1993.), izraz »nacionalna manjina« odnosi se na skupinu osoba u državi koje: a) prebivaju na teritoriju te države i njezini su državljani, b) održavaju dugotrajne, čvrste i postojane veze s tom državom, c) pokazuju distinktivna etnička, kulturna, vjerska ili jezična obilježja, d) dovoljno su reprezentativne, iako su malobrojnije od ostatka stanovništva, države ili njezine regije, e) motivirane su brigom da zajedno sačuvaju ono što konstituira njihov zajednički, identitet, uključujući njihovu kulturu, tradiciju, vjeru i jezik. Tatalović (1997: 28) utvrđuje neke karakteristike po kojima je moguće prepoznati manjine i koje mogu predstavljati osnovu za definiranje pojma: skupine koje se razlikuju; etničke, vjerske ili jezične karakteristike; broj koji je manji od polovice stanovništva; nedominirajuća situacija; državljanstvo; solidarnost; kolektivan želja za preživljavanjem; jednakost s većinom.

4 Ustavni zakon o pravima nacionalnih manjina, Narodne novine, 155/02.

5 Ustavni zakon nije akt ustavnopravnoga karaktera, što potvrđuje i Ustavni sud u obrazloženju Odluke od 7. travnja 2010. prema kojem »Ustavni zakon o Ustavnom sudu Republike Hrvatske po sili čl. 131/2. Ustava jest propis koji ima pravnu snagu samog Ustava (jer se donosi i mijenja u postupku u kojemu se donosi i mijenja Ustav), a Ustavni zakon o pravima nacionalnih manjina je po sili samog Ustava (čl. 15/2.) organski zakon koji se donosi dvotrećinskom većinom glasova svih zastupnika (čl. 82/1.). U tom smislu, neovisno o nazivu 'ustavni', Ustavni zakon o pravima nacionalnih manjina nema snagu Ustava i Ustavnog zakona o Ustavnom sudu Republike Hrvatske. (Prema Petričušić i Mikić, 2014: 1216). Više o polemici pravne prirode Ustavnog zakona i njegovu položaju u hijerarhiji pravnih propisa v. npr. Arlović (2015: 243-246). 
Analiza udjela osoba koje se izjašnjavaju kao pripadnici nacionalnih manjina i ostalih u ukupnom stanovništvu Hrvatske ${ }^{6}$ pokazuje da je u prvome međupopisnom razdoblju (1991. - 2001.) došlo do pada u njihovu udjelu. Rezultati popisa 1991. pokazuju da je udio nacionalnih manjina i ostalih u ukupnom stanovništvu bio 18,10\%. U međupopisju od 1991. do 2001. taj se udio smanjio za $59,2 \%$ uz istodoban rast udjela pripadnika hrvatskog naroda i ukupnu depopulaciju. Prema popisu 2011., udio osoba koje pripadaju nacionalnim manjinama i ostalima povećao se za 1,6\% u odnosu na prethodni popis iz 2001. Razlog tome jest smanjenje ukupnog broja stanovnika Hrvatske te udjela osoba koje ne izjašnjavaju svoju nacionalnu pripadnost i osoba čija je nacionalna pripadnost nepoznata u ukupnom stanovništvu.

Tablica 1. Promjena nacionalnog sastava stanovništva Hrvatske od 1991. do 2011.

Table 1. Changes in the ethnic composition of the Republic of Croatia 1991-2011

\begin{tabular}{|c|c|c|c|c|c|c|c|}
\hline $\begin{array}{l}\text { Nacionalna } \\
\text { pripadnost }\end{array}$ & 1991. & 2001. & 2011. & 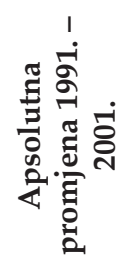 & 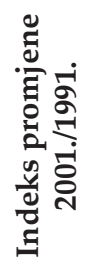 & 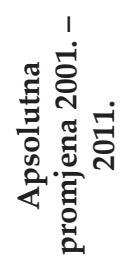 & 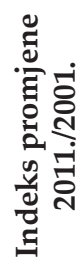 \\
\hline Hrvati & 3.736 .356 & 3.977 .171 & 3.874 .321 & 240.815 & 106,4 & -102.850 & 97,4 \\
\hline $\begin{array}{l}\text { Nacionalne } \\
\text { manjine i } \\
\text { ostali }\end{array}$ & 866.114 & 353.184 & 347.703 & -512.930 & 40,8 & -5.481 & 98,4 \\
\hline
\end{tabular}

Izvor: autoričin izračun

Najznačajnija promjena nacionalnog sastava stanovništva zabilježena je u međupopisnom razdoblju od 1991. do 2001. Tijekom tih deset godina udio Hrvata u ukupnom stanovništvu povećan je za otprilike 6\%. Istovremeno je udio pripadnika nacionalnih manjina smanjen za skoro $60 \%$. U idućemu

6 Analiza je provedena na temelju podataka Državnog zavoda za statistiku. Popisnom metodologijom nacionalna pripadnost (narodnost) definira se kao obilježje koje označuje pripadnost pojedinca narodu ili etničkoj skupini. Podaci se prikupljaju i iskazuju u modalitetima: pripadnici hrvatskog naroda, poimence pobrojene nacionalne manjine te ostali narodi koji nisu svrstani. Popisivanim osobama dana je mogućnost da izraze regionalnu pripadnost ili da ne izjasne svoju nacionalnu pripadnost. U analizi su uzeta u obzir prva tri modaliteta. 
međupopisnom razdoblju, od 2001. do 2011., broj pripadnika hrvatskog naroda smanjio se, ali se njihov udio u ukupnom stanovništvu povećao za $2,6 \%$ jer se smanjio ukupni broj stanovnika. U skladu s tim demografskim promjenama udio pripadnika nacionalnih manjina u ukupnom stanovništvu u tom razdoblju povećan je za 1,6\%. U cjelokupnom promatranom razdoblju (od 1991. do 2011.) udio osoba hrvatske nacionalne pripadnosti narastao je za 3,7\%, dok je udio pripadnika nacionalnih manjina smanjen za gotovo $60 \%$.

\section{POSEBNE MJERE ZAPOŠLJAVANJA NACIONALNIH MANJINA U JAVNOJ UPRAVI}

Pitanje odabira javnih službenika u novije se doba veže uz pitanje povećanja složenosti društva, naročito demografsko-socijalne, i s tim u vezi upravljanja različitošću (diversity management) u javnoj upravi. Prema Marčetić (2007: 192-193), to je jedna od glavnih tema7 s obzirom na odluke o odabiru ljudskih potencijala jer povećana heterogenost okoline tržišta rada, kao što su starenje stanovništva, rast obrazovane radne snage i zapošljavanje sve većeg broja žena, pred javnu upravu postavlja zahtjev učinkovitijeg upravljanja različitošću. Različitost se u kontekstu društva tradicionalno odnosi na rasnu, nacionalnu i rodnu pripadnost pojedinaca ili grupa, ali prema suvremenom shvaćanju ona obuhvaća dodatne kategorije »različitosti « pojedinaca poput dobi, invaliditeta, socijalnog statusa i vjeroispovijedi (Guy i Newman, 2005: 143).

Zapošljavanje javnih službenika koje je u demografsko-socijalnom smislu heterogeno ponajprije je vezano uz pitanje pravednosti i jednakih mogućnosti u zapošljavanju javnih službenika. U vrijeme povećane složenosti ili »različitosti« u društvenim zajednicama, dolazi naročito do izražaja simbolična uloga javne uprave kao poslodavca koji promiče takve vrijednosti (Frederickson, 2010: 137; Peters, Schröter i von Maravić, 2013: 9). No takvo zapošljavanje može pridonijeti i uspješnosti organizacije jer se ona na taj način bolje prilagođava okolišnoj raznovrsnosti. Upravno osoblje koje je po svome demografsko-socijalnom sastavu raznovrsno može se bolje prilagoditi složenoj okolini i zahtjevima koji dolaze iz takve okoline nego što je to

7 Uz pitanje upravljanja različitošću suvremena literatura o upravljanju ljudskim potencijalima ističe drugačije potrebe $u$ pogledu organizaciji dostupnih ljudskih potencijala $u$ odnosu na tradicionalno vezanje odabira kandidata uz fiksne zahtjeve određenog posla. Također, upućuje se na potrebu uspostavljanja uske dvosmjerne veze između poslovnog planiranja, kompetitivne strategije i planiranja ljudskih potencijala u javnoj upravi. Više u Marčetić (2007: 192-193). 
slučaj s homogenom radnom snagom (Guy i Newman, 2005: 144; Meier, Wrinkle i Polinardet, 1999).

Kako bi se, s jedne strane, ispunio zahtjev uklanjanja i ublaživanja učinaka diskriminatornih praksi u području zapošljavanja i, s druge, integracije različitosti u organizaciji, donose se posebne mjere zapošljavanja nacionalnih manjina u javnoj upravi. Kada se uvažavaju povijesne činjenice nejednakog postupanja prema pripadnicima manjinskih skupina, donose se mjere koje uglavnom polaze od pravno utvrđenih dimenzija diskriminacije, a definiraju ih politička tijela kao odgovor na društveni problem. Na taj se način uspostavlja vertikalna odgovornost uprave za provedbu politički utvrđenih ciljeva zapošljavanja prema višim instancijama i horizontalna prema sudskoj instanciji koja obavlja kontrolu zakonitosti. Također, one idu za postizanjem razmjerne (reprezentativne) zastupljenosti pripadnika manjinskih društvenih skupina u upravnim organizacijama u odnosu na njihovu zastupljenost u društvenoj strukturi. Najčešće je riječ o centralno utvrđenim mjerama preferencijalnog zapošljavanja među kojima se naročito izdvajaju: kvotno zapošljavanje, ciljevi zapošljavanja ${ }^{8}$ i unaprijed rezervirana radna mjesta. U suvremeno doba primjenjuju se metode koje ne polaze isključivo od problema diskriminacije, već pomiču interes prema većoj uspješnosti organizacija putem različitosti. Najčešće se pritom primjenjuju sljedeće mjere: poticanje zapošljavanja (aktivne mjere poticanja zapošljavanja kao što su financijske potpore ili nagrade rukovoditeljima koji uspješno ispunjavaju planove zapošljavanja), promidžbene kampanje i ciljano oglašavanje (upravna organizacija izravno se obraća određenim društvenim skupinama koje su nedovoljno zastupljene ili čak podzastupljene u organizaciji u odnosu na sociodemografski sastav stanovništva). ${ }^{9}$

\section{Posebne mjere $\mathbf{u}$ hrvatskom zakonodavstvu}

U hrvatskome pravnom sustavu posebne mjere zapošljavanja pojedinih društvenih skupina ${ }^{10}$ postoje još od osamostaljenja Republike Hrvatske. Pojedinim propisima posebne se mjere ne definiraju. Njihov se cilj i opseg

Iako se kvotama i ciljevima zapošljavanja utvrđuju brojčano iskazani ciljevi, među njima postoji jedna vrlo značajna razlika. Kvote su čvrsto iskazani brojčani cilj zapošljavanja iza kojeg stoji mehanizam državnih sankcija i sudske zaštite. Za razliku od kvota ciljevi zapošljavanja predstavljaju fleksibilne brojčano iskazane ciljeve i indikatore željene razine zastupljenosti pripadnika manjinskih skupina (Riccucci, 2005: 413).

9 Za širu raspravu o posebnim mjerama zapošljavanja manjina u odabranim zemljama v. Vukojičić Tomić (2017).

10 Preciznije, riječ je o braniteljima i članovima njihovih obitelji, nacionalnim manjinama i osobama s invaliditetom. 
prvi put definiraju 2008. godine Zakonom o suzbijanju diskriminacije, ${ }^{11}$ a odnose se, između ostaloga, i na područje zapošljavanja, rada i radnih uvjeta. Zakon ih određuje kao iznimku od zabrane diskriminacije, u skladu s pravnom stečevinom EU-a. Posebne se mjere, unošenjem direktiva EU-a i usklađivanjem sa sudskom praksom Suda pravde Europske unije, od 2012. tumače restriktivnije $u$ odnosu na prethodni zakon iz 2008. stavljanjem naglaska na privremenu narav posebnih mjera radi ostvarivanja stvarne (materijalne), a ne formalne jednakosti.

Zapošljavanje nacionalnih manjina u hrvatskoj javnoj upravi propisuje se kao pravo na zastupljenost, a zajamčena je nacionalnim manjinama ustavnim zakonom još od 1991. Prvi Ustavni zakon koji regulira pitanje prava nacionalnih manjina, $\mathrm{u}$ okviru šireg pristupa zaštite ljudskih prava i sloboda čovjeka, donesen je u prosincu 1991. ${ }^{12}$ Ustavni zakon donosi se u skladu s nizom međunarodnih standarda o ljudskim pravima i slobodama i pravima nacionalnih manjina, a sadržajno uređuje: prava i slobode čovjeka, a osobito zaštitu ravnopravnosti etničkih i nacionalnih zajednica ili manjina, kulturnu autonomiju i druga srodna prava etničkih i nacionalnih zajednica ili manjina, pravo na proporcionalno sudjelovanje u predstavničkim i drugim tijelima Republike Hrvatske i jedinica lokalne samouprave te poseban samoupravni položaj općina u kojima Srbi čine natpolovičnu većinu. ${ }^{13}$ Čl. 18. utvrđuje pravo etničkih i nacionalnih zajednica i manjina, čiji je udio u stanovništvu iznad $8 \%$, na zastupljenost razmjerno svom udjelu u ukupnom stanovništvu (razmjerna zastupljenost) u Saboru i Vladi RH te u tijelima vrhovne sudbene vlasti, a pripadnicima zajednica čiji je udio manji od $8 \%$ jamči se izbor od ukupno pet zastupnika u Zastupnički dom Sabora. Uz tu se odredbu veže i pravo manjina prema tako utvrđenom postotnom udjelu na zastupljenost u drugim tijelima državne vlasti, što se osigurava

11 Narodne novine, 85/08, 112/12.

12 Narodne novine, 56/91.

13 Prema Arloviću (2015: 192), riječ je o postojanju i razlikovanju nacionalnih manjina i etničkih skupina koje se uspostavlja ovim Ustavnim zakonom, čime se željela opravdati prihvaćena de facto privilegiranost srpske nacionalne manjine u odnosu na druge manjine utvrđivanjem prava na teritorijalnu autonomiju u općinama gdje ona čini većinu stanovništva, ali i posebni status u sudbenoj i upravnoj vlasti koji se veže uz postotni udio u stanovništvu, a koji ispunjava samo srpska nacionalna manjina. Drugačije stajalište izražava Omejec, koja smatra da normativno određenje »etničkih i nacionalnih zajednica ili manjina« otežava razradu položaja i prava manjina u Hrvatskoj, osobito stoga što ni Ustavni zakon ni bilo koji drugi zakon ne sadržava mjerilo prema kojem bi se pojedini manjinski narod mogao smatrati »nacionalnom «, odnosno »etničkom « manjinom, niti je jasno normativno razlikovanje između »zajednice« $i$ »manjine« (Omejec, 2000: 648-649). Povrh toga, Ustavni zakon ne određuje postupak po kojem bi etničke i nacionalne zajednice ili manjine koje u zakonu nisu izrijekom spomenute mogle dobiti taj status. 
zakonom o ustrojstvu državne vlasti (čl. 18. st. 5.), te pravo na razmjernu zastupljenost u tijelima lokalne samouprave, a postupak osiguravanja tog prava utvrđuje se zakonom kojim se uređuje lokalna samouprava i statutom jedinice lokalne samouprave (čl. 19.). Zakon o sustavu državne uprave iz 1993. ${ }^{14}$ (dalje: ZSDU) u čl. 8. osigurava zastupljenost pripadnika etničkih ili nacionalnih zajednica ili manjina u ministarstvima i državnim upravnim organizacijama, vodeći računa o njihovu ukupnom udjelu u stanovništvu Republike Hrvatske, a u županijskim, odnosno gradskim uredima vodeći računa o njihovu ukupnom udjelu u stanovništvu županije, odnosno Grada Zagreba, ne propisujući pritom ograničenje iz članka 18. Ustavnog zakona o $8 \%$ udjela u stanovništvu. U nastavku se određuje da Vlada RH nadzire provedbu zastupljenosti pripadnika etničkih ili nacionalnih zajednica ili manjina u tijelima državne uprave. U pogledu ostvarenja prava na zastupljenost u tijelima lokalne samouprave, Ustavni zakon predviđa da će postupak osiguravanja tog prava biti utvrđen zakonom o lokalnoj samoupravi. No tek je 2005., usklađivanjem s novim Ustavnim zakonom iz 2002., osigurana zastupljenost nacionalnih manjina u upravnim tijelima lokalne i područne (regionalne) samouprave. Sve dotada posebnim zakonom te njegovim izmjenama i dopunama nije bilo uređeno ostvarivanje tog prava.

Provedbu prava na razmjernu zastupljenost u tijelima državne uprave i tijelima jedinica lokalne samouprave koju predviđa Ustavni zakon iz 1991. otežava nekoliko okolnosti. Prvo, u relevantnim odredbama prisutna je terminološka neusklađenost u pogledu tijela u kojima manjine imaju pravo na zastupljenost jer se nedosljedno upotrebljavaju termini »druga tijela držav-

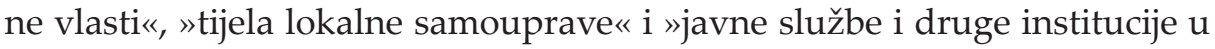
ovom području«. Također, iz tih odredbi nije jasno koja su tijela obuhvaćena upotrijebljenim terminima, osobito kad je riječ o lokalnoj samoupravi s obzirom na činjenicu da posebnim zakonom to pravo nije detaljnije uređeno, što je ujedno i drugi značajan problem vezan uz provedbu prava na razmjernu zastupljenost. Treće, način provedbe tog prava, točnije način na koji će se popuniti radna mjesta tako da se ispuni zahtjev razmjernosti nije uopće uređen. Četvrto, u pogledu nadležnosti za praćenje provedbe tih odredbi, može se primijetiti pravna neusklađenost. Ustavni zakon nadležnim određuje Vladin Ured za međunacionalne odnose, dok Zakon o sustavu državne uprave, koji je donesen gotovo dvije godine poslije, propisuje nadležnost Vlade $\mathrm{u}$ tom pitanju.

14 Narodne novine, 75/93, 48/99, 15/00, 127/00-vjerodostojno tumačenje, 59/01, 190/03-pročišćeni tekst, 199/03, 79/07. 
Već u rujnu 1995. suspendira se primjena prava na razmjernu zastupljenost nacionalnih manjina sukladno čl. 18. Ustavnog zakona iz 1991. donošenjem Ustavnog zakona o privremenom neprimjenjivanju pojedinih odredbi Ustavnog zakona o ljudskim pravima i slobodama i o pravima etničkih i nacionalnih zajednica ili manjina u Republici Hrvatskoj. ${ }^{15}$ Prava nacionalnih manjina na zastupljenost $\mathrm{u}$ tijelima lokalne samouprave prema čl. 19. Ustavnog zakona iz 1991. tim Ustavnim zakonom nisu suspendirana, ali s obzirom na činjenicu da posebnim zakonom kojim se uređuje lokalna samouprava, što predviđa Ustavni zakon iz 1991., nikad nije uređen način ostvarivanja tog prava, valja pretpostaviti da se navedene odredbe nisu ni primjenjivale.

Zbog posljedica koje je Ustavni zakon iz 1995. izazvao u pogledu ostvarenja prava na razmjernu zastupljenost nacionalnih manjina, u svibnju 2000. Odbor za Ustav, Poslovnik i politički sustav Zastupničkog doma podnosi Prijedlog Ustavnog zakona o izmjenama i dopunama Ustavnog zakona o ljudskim pravima i slobodama i o pravima etničkih i nacionalnih zajednica ili manjina u Republici Hrvatskoj br. $44 .{ }^{16} \mathrm{Uz}$ neke novine ${ }^{17} \mathrm{u}$ pogledu prava na zastupljenost u tijelima državne uprave odredba o privremenom neprimjenjivanju odredbe o pravu na zastupljenost nacionalnih manjina samo se mijenja u odredbu prema kojoj će se »Odredba članka 18. stavka 1., dio odredbe stavka 4., koja se odnosi na način izbora i opoziva zastupnika iz stavka 1., te odredbe stavka 5. primjenjivat će se od objave rezultata sljedećeg popisa stanovništva Republike Hrvatske« (čl. 12.). O toj promjeni može se reći da su implikacije ostale iste - pravo na zastupljenost nacionalnih manjina odgađa se do popisa stanovništva - samo je došlo do terminološke transformacije iz negativne formulacije (»privremeno neprimjenjivanje pojedinih odredbi«) u pozitivnu formulaciju (»primjenjivat će se «) prava na zastupljenost, što obuhvaća i zastupljenost u tijelima državne uprave.

15 Narodne novine, 68/95.

16 Prijedlog Ustavnog zakona o ljudskim pravima i slobodama i o pravima etničkih i nacionalnih zajednica ili manjina u Republici Hrvatskoj br. 44 zaprimljen je 31. ožujka 2016. od Službe za medije Hrvatskog sabora temeljem Zahtjeva za pristup informacijama koji je toj službi upućen 28. ožujka 2016.

17 Sljedeća se pitanja uređuju prijedlogom Ustavnog zakona: (a) izrijekom se navode postojeće nacionalne manjine u Hrvatskoj i otvara se mogućnost proširenja njihova broja i pripadnicima drugih naroda koji se tijekom vremena mogu konstituirati kao nacionalna manjina; (b) stavljaju se izvan snage odredba čija primjena u današnjim okolnostima nema osnova; (c) uređuje se proporcionalna zastupljenost nacionalnih manjina čiji je udio u stanovništvu veći od $8 \%$ i zastupljenost nacionalnih manjina čiji je udio u stanovništvu manji od $8 \%$ u Hrvatskome državnom saboru. 
Ustavni zakon o pravima nacionalnih manjina ${ }^{18}$ donosi se $\mathrm{u}$ prosincu 2002. Cilj donošenja novog Ustavnog zakona jest da, osim njegova usklađivanja s Ustavom RH i međunarodnim ugovorima kojih je RH sudionik i potrebe da se u skladu s njima urede prava i slobode pripadnika nacionalnih manjina i njihova zaštita, i stvaranje pravnog okvira koji će biti poticajan za održavanje etničke i multikulturne raznolikosti, te razvijanja duha razumijevanja, uvažavanja i tolerancije s ciljem doprinosa promicanju razvoja Republike Hrvatske. Ustavni zakon sadržajno je usklađen s Okvirnom konvencijom i obuhvaćene su sve tzv. generacije prava manjina: pravo na slobodno izjašnjavanje o pripadnosti nacionalnoj manjini i jednakost pred zakonom bez diskriminacije, pravo na očuvanje vlastitog jezika, kulture, vjere i tradicije te pravo na sudjelovanje u kulturnome, gospodarskom, političkom i javnom životu. U okviru prava manjina na sudjelovanje u odlučivanju, koje predstavlja najrecentniju grupu prava, uređeno je i njihovo pravo na zastupljenost $\mathrm{u}$ tijelima državne uprave i pravosudnim tijelima, te tijelima jedinica lokalne samouprave i područne (regionalne) samouprave, na način i pod uvjetima propisanim ovim Ustavnim zakonom i posebnim zakonima. Za razliku od prethodnog Ustavnog zakona iz 1991. i njegovih izmjena i dopuna, ovaj Ustavni zakon ne određuje koje se nacionalne skupine imaju smatrati nacionalnim manjinama u RH. Pravo nacionalnih manjina na zastupljenost $u$ tijelima države uprave, pravosudnim tijelima i u upravnim tijelima u jedinicama lokalne i područne (regionalne) samouprave vezuje se, kao i u prethodnom zakonu, uz pravo na političku zastupljenost. ${ }^{19}$ Prema čl. 22. st. 2., 3. i 4., pripadnicima nacionalnih manjina

18 Narodne novine, 155/02, 47/10, 80/10, 93/11.

19 Političku zastupljenost nacionalnih manjina moguće je osigurati primjenom barem pet izbornih tehnika (Omejec, 2000: 667-671). Prva, i najčešće upotrebljavana, jest tehnika unaprijed rezerviranih mjesta za manjine u predstavničkom tijelu (može se primijeniti i na izvršna tijela, op. a.), pri čemu se predstavnici određenih manjinskih skupina u pravilu biraju na istovjetni način kao i drugi članovi predstavničkog tijela. Druga tehnika javlja se kao dopunska izborna tehnika prethodnoj, a odnosi se na slučajeve kad predstavnike manjina biraju samo članovi određene manjinske zajednice na posebnim popisima birača. Ta je tehnika danas napuštena jer najčešće izaziva suprotni učinak od željenoga, odnosno koči prirodnu političku izmiješanost nacionalnih zajednica, a teško ju je i praktično provesti, a da se pritom osigura pravična distribucija mjesta među manjinskim skupinama. Primjenom treće tehnike natpredstavljaju se određena područja države (npr. regije). Na taj se način unaprijed oblikuje struktura koja će prirodnim putem, umjesto zakonskom obligacijom, dovesti do parlamentarne reprezentacije manjina. Četvrta je tehnika sustav najuspješnijega gubitnika ('best loser' system) u kojem se najviše rangiranim kandidatima, koji nisu izabrani, dodjeljuje zastupničko mjesto iako nisu prešli izborni prag. Posljednja, ujedno i najkontroverznija tehnika jest manipulacija pri krojenju izbornih jedinica, $t z v$. afirmativni ili pozitivni gerrymandering. Izborne jedinice kroje se tako da u njima većinu imaju pripadnici određene manjinske skupine, a nailazi na brojne kritike jer se općeni- 
osigurava se zastupljenost $u$ tijelima državne uprave i pravosudnim tijelima sukladno odredbama posebnog zakona, vodeći računa o sudjelovanju pripadnika nacionalnih manjina u ukupnom stanovništvu na razini na kojoj je ustrojeno tijelo državne uprave ili pravosudno tijelo i stečenim pravima. Također, osigurava im se zastupljenost u tijelima uprave jedinica samouprave sukladno odredbama posebnog zakona kojim se uređuje lokalna i područna (regionalna) samouprava i sukladno stečenim pravima.

U popunjavanju tih mjesta predstavnici nacionalnih manjina ostvaruju pravo prednosti pod istim uvjetima. Ova je posljednja odredba naročito važna jer je time naposljetku propisan način na koji tijela javne uprave mogu osigurati propisanu zastupljenost nacionalnih manjina, što do donošenja ovog Ustavnog zakona nije bio slučaj. Ona omogućuje da se, u skladu s primjenom merit kriterija za zapošljavanje u javnoj upravi, primi onaj kandidat koji ispunjava sve uvjete iz javnog natječaja. Istodobno, to je u skladu s čl. 4. st. 2. i 3. Okvirne konvencije, prema kojem se stranke obvezuju »da će po potrebi usvojiti odgovarajuće mjere s ciljem promicanja pune i učinkovite jednakosti između pripadnika nacionalne manjine i pripadnika većinskog pučanstva u svim područjima gospodarskog, društvenog, političkog i kulturnog života. U svezi s tim stranke će na odgovarajući način uzeti u obzir specifičnosti pripadnika nacionalnih manjina. Mjere usvojene u skladu sa stavkom 2. ne smatraju se činom diskriminacije.« Treba također istaknuti i shvaćanje Ustavnog suda RH izraženo u odluci od 12. travnja $2001 .^{20} \gg$ da zakonsko osiguranje prava pripadnika nacionalnih manjina na zastupljenost

to smatra da su bilo kakve manipulacije u izbornom sustavu kontroverzne. Hrvatski je zakonodavac u pogledu prava na političku zastupljenost nacionalnih manjina prihvatio tehniku unaprijed rezerviranih manjinskih mjesta u predstavničkim i drugim tijelima političke vlasti, praveći razliku u broju tih mjesta s obzirom na postotak zastupljenosti pojedine manjinske skupine u ukupnom stanovništvu (Omejec, 2000: 673; Mesić, 2013: 123). Propisivanjem takva oblika kvotnog sustava reprezentacije Hrvatska je, prema Omejec, izrazila svoj ustavnopravni cilj, a to je da manjinske skupine treba integrirati u politički život zemlje jer bi u suprotnome bile izložene riziku političke marginalizacije. Unatoč tome s primjenom takva načela treba biti oprezan jer je općeprihvaćeno stajalište da ga je opravdano »normativno predvidjeti samo za onoliko dugo razdoblje koliko je potrebno da bi se prevladali uzroci stanja koji su doveli do potrebe njegova uvođenja u izbornopravni poredak neke zemlje« (Santolaya i Iñiguez, 1998, prema Omejec, 2000: 673). Mesić upućuje kritiku tehnici rezerviranih mandata manjinskih predstavnika u Saboru kao konceptualno nedomišljenoj koja proizlazi iz nerazumijevanja manjinske problematike za suvremena demokratska društva (Mesić, 2013: 124). Taj koncept naime počiva na pretpostavkama koje su međusobno nespojive: prva je da su izabrani manjinski zastupnici predstavnici kolektivnih manjinskih zajednica, a druga da su manjinski zastupnici etnički odnosno nacionalni predstavnici, te da ih se u tom kapacitetu može apstrahirati od njihovih političkih orijentacija i stranačkih afilijacija.

20 Odluka i rješenje broj: U-I-732/1998, Narodne novine, 36/2001. 
u tijelima državne vlasti se ne može ocijeniti nesuglasnim prihvaćenom i zajamčenom načelu pozitivne diskriminacije iz članka 15. stavka 3. Ustava Republike Hrvatske, a temelji se i na načelima sadržanim u Okvirnoj konvenciji za zaštitu nacionalnih manjina «. ${ }^{21}$

Posebnim zakonima osigurano je pravo nacionalnih manjina na zastupljenost $u$ tijelima javne uprave. Čl. 8. ZSDU-a ${ }^{22}$ osigurava pripadnicima nacionalnih manjina iz članka 22. stavka 2. Ustavnog zakona zastupljenost u ministarstvima i državnim upravnim organizacijama, vodeći računa o njihovu ukupnom udjelu u stanovništvu, a u uredima državne uprave u jedinicama područne (regionalne) samouprave vodeći računa o njihovu ukupnom udjelu u stanovništvu županije. Provedbu zastupljenosti pripadnika nacionalnih manjina u tijelima državne uprave nadzire Vlada RH. Zakon o državnim službenicima ${ }^{23}$ detaljnije utvrđuje ostvarivanje prava prednosti pri zapošljavanju u odredbama o obvezatnom planiranju zapošljavanja, odnosno obvezi donošenja planova prijma u službu. Čl. 42. st. 2. određuje da se planom prijma u državnu službu utvrđuje »popunjenost radnih mjesta $\mathrm{u}$ državnom tijelu pripadnicima nacionalnih manjina i planira zapošljavanje potrebnog broja državnih službenika pripadnika nacionalnih manjina radi ostvarivanja zastupljenosti sukladno Ustavnom zakonu o pravima nacionalnih manjina i zakonu kojim se uređuje sustav državne uprave«. Način ostvarenja prava na zastupljenost propisuje čl. 45. st. 3., prema kojem je kandidat koji ima pravo prednosti kod prijma u državnu službu prema posebnom zakonu, dužan u prijavi na natječaj pozvati se na to pravo i ima prednost $\mathrm{u}$ odnosu na ostale kandidate samo pod jednakim uvjetima.

Izmjenama i dopunama Zakona o lokalnoj i područnoj (regionalnoj) samoupravi iz 2005. ${ }^{24}$ unesena je odredba o pravu na zastupljenost manjina $\mathrm{u}$ izvršnim i upravnim tijelima tih jedinica kao rezultat usklađivanja zakona s Ustavnim zakonom iz 2002. Tako je nakon više od deset godina od donošenja Ustavnog zakona koji propisuje pravo nacionalnih manjina na zastupljenost $\mathrm{u}$ upravnim tijelima jedinica lokalne i regionalne samouprave, posebnim zakonom uređeno to pravo. Prema čl. 56a, pripadnici nacionalnih manjina koji sukladno odredbama čl. 20. Ustavnog zakona iz 2002. imaju pravo na razmjernu zastupljenost u predstavničkim tijelima jedinice

${ }_{21}$ Konačni prijedlog Ustavnog zakona br. 536, str. 24. Konačni prijedlog zaprimljen je 5. travnja 2016. od Službe za medije Hrvatskog sabora temeljem Zahtjeva za pristup informacijama koji je toj službi upućen 4. travnja 2016.

22 Narodne novine, 190/03 - pročišćeni tekst.

23 Narodne novine, 92/05, 142/06, 77/07, 107/07, 27/08, 34/11, 49/11, 150/11, 34/12, 49/12, 37/13, $38 / 13,01 / 15,138 / 15$.

24 Narodne novine, 129/05. 
lokalne i područne (regionalne) samouprave, imaju pravo na zastupljenost u izvršnim i upravnim tijelima tih jedinica. Planom prijma u službu utvrđuje se popunjenost upravnih tijela jedinica lokalne i područne (regionalne) samouprave i planira zapošljavanje potrebnog broja pripadnika nacionalnih manjina radi ostvarivanja zastupljenosti, a pripadnici nacionalnih manjina imaju pravo prilikom podnošenja prijave na natječaj za prijam $u$ službu pozvati se na ostvarivanje prava koje im pripadaju sukladno odredbama Ustavnog zakona.

Posebnim odredbama uređuje se nadzor koji tijela državne uprave $u$ pitanjima iz svog djelokruga provode nad ostvarivanjem prava i sloboda nacionalnih manjina zajamčenih Ustavom, Ustavnim zakonom i posebnim zakonima (čl. 37.). Rad tijela državne uprave u primjeni Ustavnog zakona i posebnih zakona usklađuje Vlada, koja Saboru najmanje jednom godišnje podnosi izvješće o provođenju Ustavnog zakona. Propisuje se i ovlast posebnih političkih institucija nacionalnih manjina koje ovaj Ustavni zakon osniva, vijeća odnosno predstavnika nacionalnih manjina i Savjeta za nacionalne manjine, ${ }^{25}$ da zatraže od nadležnog tijela državne uprave odnosno Vlade provedbu nadzora nad primjenom Ustavnog zakona kao i da podnesu ustavnu tužbu Ustavnom sudu Republike Hrvatske ako po vlastitoj ocjeni ili povodom inicijative pripadnika nacionalne manjine smatraju da su povrijeđena prava i slobode pripadnika nacionalnih manjina propisana Ustavnim zakonom i posebnim zakonima (čl. 38.).

Izmjene Ustavnog zakona iz $2010 .{ }^{26}$ donose manje izmjene $u$ pogledu prava nacionalnih manjina na zastupljenost $\mathrm{u}$ tijelima javne uprave. Člankom 22. st. 2. i 3. određuje se da se zastupljenost osigurava, uz odredbe posebnog zakona, još i drugim aktima o politici zapošljavanja u tim tijelima. Riječ je o usklađivanju ustavnozakonskih odredbi s praksom državnih i lokalnih upravnih tijela da zapošljavanje planiraju na godišnjoj razini planovima prijma u službu.

25 Uz pravo na zastupljenost manjina u predstavničkim i izvršnim tijelima, Ustavni zakon iz 2002. uređuje i izbor vijeća i predstavnika nacionalnih manjina u jedinicama lokalne i područne (regionalne) samouprave s ciljem unapređivanja, očuvanja i zaštite položaja nacionalnih manjina u društvu (čl. 23. do 34.). Također, osniva Savjet za nacionalne manjine, čije članove imenuje Vlada, radi sudjelovanja nacionalnih manjina u javnom životu Republike Hrvatske, a osobito radi razmatranja i predlaganja uređivanja i rješavanja pitanja u svezi s ostvarivanjem i zaštitom prava i sloboda nacionalnih manjina (čl. 35. i čl. 36.).

26 Narodne novine, 80/10. 


\section{ANALIZA PODATAKA O ZAPOSLENOSTI NACIONALNIH MANJINA U HRVATSKOJ JAVNOJ UPRAVI}

Zapošljavanje nacionalnih manjina u javnoj upravi u potpunosti je pravno uređeno od 2002. na način da im se osigurava zastupljenost u tijelima državne uprave, pravosudnim tijelima i upravnim tijelima jedinica lokalne i područne samouprave. No podaci o njihovu zapošljavanju prikupljaju se od 2006. Nadalje, podaci o njihovu udjelu u ukupnom broju zaposlenih u tijelima državne uprave analiziraju se od 2008., a u upravnim tijelima jedinica lokalne i područne (regionalne) samouprave od 2009. (v. tablicu 2). ${ }^{27}$ Podaci su dostupni u Izvješćima o provođenju Ustavnog zakona o pravima nacionalnih manjina i o utrošku sredstava osiguranih u državnom proračunu Republike Hrvatske za potrebe nacionalnih manjina koja Vlada Republike Hrvatske podnosi Hrvatskom saboru jednom godišnje (Vlada RH, 2008 - 2015).

Tablica 2. Broj zaposlenih osoba pripadnika nacionalnih manjina te njihov postotni udio u ukupnom broju zaposlenih osoba $\mathrm{u}$ tijelima državne uprave (TDU) i upravnim tijelima jedinica lokalne i područne (regionalne) samouprave (JLP/R/S) po godinama

Table 2. The number of employed members of national minorities and their percentage share in the total number of employees in the state administration bodies and administration bodies of local and regional self-government units

\begin{tabular}{lccccccccccc}
\hline $\begin{array}{l}\text { Pripadnici } \\
\text { nacionalnih } \\
\text { manjina }\end{array}$ & 2006. & 2007. & 2008. & 2009. & 2010. & 2011. & 2012. & 2013. & 2014. & 2015. \\
\hline \multirow{2}{*}{ TDU } & $\mathrm{N}$ & 1987 & 2031 & 2216 & 2247 & 2070 & 1779 & 1752 & 1853 & 1762 & 1713 \\
\cline { 2 - 11 } & $\%$ & na & na & 4,2 & 4,2 & 3,9 & 3,4 & 3,4 & 3,5 & 3,5 & 3,4 \\
\hline & $\mathrm{N}$ & 411 & 522 & 597 & 609 & 584 & 592 & 594 & 563 & 526 & 512 \\
\hline JLP(R)S & $\%$ & na & na & na & 4,7 & 4,5 & 4,6 & 4,6 & 4,3 & 3,8 & 3,8 \\
\hline
\end{tabular}

Izvor: autoričin izračun na temelju podataka iz godišnjih Izvješća o provođenju Ustavnog zakona o pravima nacionalnih manjina i o utrošku sredstava osiguranih u državnom proračunu Republike Hrvatske za potrebe nacionalnih manjina Vlada Republike Hrvatske 2008 - 2015. Podaci za 2015. godinu dobiveni su temeljem zahtjeva upućenog Ministarstou uprave 1. veljače 2016.

Podaci o udjelu nacionalnih manjina nisu bili dostupni prethodnih godina jer nije bio poznat ukupni broj zaposlenih u tijelima javne uprave. 
Analiza podataka o broju zaposlenih pripadnika nacionalnih manjina $\mathrm{u}$ tijelima državne uprave od 2006. do 2015. pokazuje pad u broju zaposlenih, odnosno smanjenje postotnog udjela nacionalnih manjina u ukupnom broju zaposlenih službenika i namještenika. Moguće je uočiti dvije stvari. Prvo, riječ je o stalnome, kontinuiranom smanjenju broja zaposlenih u desetogodišnjem razdoblju, izuzev 2013. i 2014., kada dolazi do laganog porasta. ${ }^{28}$ Od 2006. do 2015. njihov je broj smanjen za 274 (indeks promjene 0,86). Drugo, udio pripadnika nacionalnih manjina u ukupnom broju zaposlenih od 2008. do 2015. pada s $4,2 \%$ na $3,4 \%$. Pritom valja imati na umu da je njihov udio u ukupnom stanovništvu otprilike $8 \%$.

Kad se analizira broj zaposlenih pripadnika nacionalnih manjina i njihov udio u ukupnom broju zaposlenih u upravnim tijelima jedinica lokalne $\mathrm{i}$ područne (regionalne) samouprave, dolazi se do sličnih rezultata. U promatranom razdoblju broj manjinskih službenika i namještenika neznatno se mijenja uz stalni blagi pad tijekom godina, dok udio pripadnika nacionalnih manjina u ukupnom broju zaposlenih kontinuirano pada (indeks promjene 0,81 ). Istovremeno se smanjuje i broj jedinica koje su dužne osigurati zastupljenost pripadnika nacionalnih manjina u svojim upravnim tijelima. ${ }^{29}$ Za ilustraciju, od 78 jedinica koje su dužne osigurati zastupljenost u 2014. to se pravo u cijelosti ostvaruje u njih 57 , što $u$ odnosu na prethodnu godinu znači da je broj jedinica koje osiguravaju zastupljenost smanjen za jednu jedinicu lokalne i područne (regionalne) samouprave. U 2015. godini to se pravo $u$ cijelosti ostvaruje $u$ njih 56 , što opet predstavlja smanjenje $u$ odnosu na prethodnu godinu. Istodobno se međutim povećava broj lokalnih jedinica koje zapošljavaju pripadnike nacionalnih manjina iako nisu dužne osigurati njihovu zastupljenost. Tako npr. 2015. ukupno 128 jedinica osigurava zastupljenost, što predstavlja povećanje od sedam lokalnih jedinica u odnosu na prethodnu godinu.

Analiza zapošljavanja pripadnika nacionalnih manjina u hrvatskoj javnoj upravi upućuje na nezadovoljavajuće učinke trenutačnog modela nji-

28 Treba napomenuti da se od 2013. primjenjuje novi način obrade podataka, i to uparivanjem registra birača koji sadržava podatak o nacionalnosti birača i registra zaposlenih u državnoj službi. Nije isključeno da je do promjene, tj. statističkog porasta broja zaposlenih došlo zbog primjene nove metode prikupljanja i analize podataka. Lokalne jedinice u kojima je udio nacionalnih manjina manji mogu općim aktom propisati obvezu zapošljavanja pripadnika manjina u svojim upravnim tijelima.

29 Obvezu zapošljavanja pripadnika nacionalnih manjina u upravim tijelima lokalnih jedinica, sukladno Ustavnom zakonu i Zakonu o lokalnoj i područnoj (regionalnoj) samoupravi, imaju općine i gradovi u kojima pripadnici manjina u stanovništvu sudjeluju s više od 15\% te županije u kojima manjine sudjeluju s više od 5\%, odnosno jedinice koje imaju obvezu osigurati razmjernu zastupljenost pripadnika manjina u predstavničkom tijelu. 
hova zapošljavanja. S jedne strane, bilježi se stalni pad u broju zaposlenih i udjelu nacionalnih manjina $u$ ukupnom broju zaposlenih službenika i namještenika. Ne manje važno, primjenom ciljeva zapošljavanja kao jedine i isključive mjere preferencijalnog zapošljavanja ne ostvaruje se zakonom zajamčena zastupljenost pripadnika nacionalnih manjina $u$ tijelima javne uprave. Iskustva nekih europskih zemalja idu u prilog toj tvrdnji pa se stoga posljednjih godina sve više primjenjuju dodatne mjere kao što su poticanje zapošljavanja, promidžbene kampanje i ciljano oglašavanje.

U izvješću Vlade RH o provođenju Ustavnog zakona o pravima nacionalnih manjina (Vlada RH, 2015) i Okvirne konvencije za zaštitu nacionalnih manjina (Vlada RH, 2014a) navodi se kako se zabrana zapošljavanja u državnoj službi u najvećoj mjeri odražava na zapošljavanje uopće, pa i za nacionalne manjine. Naime od 2009. na snazi je Odluka o zabrani novog zapošljavanja državnih službenika i namještenika u tijelima državne uprave, stručnim službama i uredima Vlade Republike Hrvatske..$^{30}$ Iznimno se dozvoljava zapošljavanje na radna mjesta koja ostanu upražnjena zbog prestanka službe državnog službenika ili rada namještenika ako nije moguće osigurati redovito obavljanje poslova preraspodjelom između postojećih državnih službenika i namještenika, primjenom klauzule 2 za 1 (za dva otišla jedan novi zaposleni). Prijam u državnu službu na neodređeno vrijeme moguć je samo ako je predviđen planom prijma u državnu službu.

Iako takva odluka Vlade nedvojbeno utječe na pad broja zaposlenih državnih službenika i namještenika uopće i iz reda pripadnika nacionalnih manjina, ona ipak ne objašnjava u potpunosti stalno smanjenje udjela nacionalnih manjina u ukupnom broju zaposlenih, osobito u upravnim tijelima jedinica lokalne i područne (regionalne) samouprave na koja se ta odluka ne odnosi. Također, planom prijma u državnu službu svake se godine planira zapošljavanje određenog broja pripadnika nacionalnih manjina.

Stoga treba, s jedne strane, više učiniti u pogledu obavještavanja kandidata o potrebi izjašnjavanja o nacionalnoj pripadnosti jer je to jedini način da ostvare pravo prednosti pri zapošljavanju te, s druge, razmotriti uvođenje dodatnih i komplementarnih mjera posebnih oblika zapošljavanja nacionalnih manjina.

No Narodne novine, 153/09, 114/14. 


\section{ZAKLJUČAK}

Posebne se mjere zapošljavanja nacionalnih manjina u javnoj upravi tijekom devedesetih godina 20. stoljeća uglavnom nisu provodile, pa je moguće govoriti o fazi u kojoj dolazi do regresije prava na zapošljavanje. Situacija u kojoj zakoni inicijalno uvode posebne mjere zapošljavanja koje se u praksi ne provode traje sve do početka 21. stoljeća. U narednom razdoblju dolazi do postupnog unapređenja zakonskih rješenja i stvaranja pretpostavki uspostavljanja cjelovitog sustava zapošljavanja i rada nacionalnih manjina. U toj je fazi osobito izražen utjecaj normativnog usklađivanja s pravnom stečevinom EU-a i europskim standardima radi preuzetih obveza iz pretpristupnog partnerstva, a propisi se usto usklađuju i s pravnim aktima Vijeća Europe. U tom smislu promjene se tiču prenošenja odredbi iz relevantnih direktiva, ali i zakonskih rješenja za koje se ističe da su usklađena sa suvremenim europskim i međunarodnim trendovima i dobrim praksama.

Unatoč tome što su u posljednja dva desetljeća učinjeni značajni napori i poduzete mjere koje trebaju pridonijeti ravnomjernijoj zastupljenosti nacionalnih manjina u tijelima javne uprave, provedena analiza upućuje na probleme u provedbi posebnih oblika njihova zapošljavanja.

Prvi, ujedno i ključni problem odnosi se na praćenje i izvještavanje o ispunjavanju utvrđenih ciljeva i vremenskog plana zapošljavanja. Posebni oblici zapošljavanja manjina ostvaruju se primjenom tzv. posebnih mjera. Definirajući posebne mjere, hrvatski zakonodavac prihvatio je međunarodne i europske standarde koji posebno naglašavaju njihovu privremenu narav. One su definirane kao mjere koje su prikladne i nužne za ostvarivanje stvarne jednakosti društvenih skupina koje su u nepovoljnijem položaju i koje trebaju trajati onoliko dugo koliko je potrebno da se ostvari cilj stvarne jednakosti. Kako bi to bilo moguće, postavljeni ciljevi posebnih oblika (preferencijalnog) zapošljavanja moraju sadržavati mjerila za nadzor rezultata ili pokazatelje uspješnosti koji omogućuju vrednovanje rezultata te rokove provedbe zadanih ciljeva. Jedan od osnovnih preduvjeta nadzora, analize i vrednovanja ostvarenih rezultata jest sustavno praćenje vrsta mjera koje se provode. U Hrvatskoj još uvijek ne postoji pouzdan i sveobuhvatan instrumentarij kojim se sustavno analizira primjena posebnih mjera zapošljavanja te razmatra opravdanost primjene postojećih mjera i eventualno uvođenje drugačijih ili dodatnih mjera; posebno stoga što njihova primjena ne dovodi do zadovoljavajućih rezultata. Analiza podataka o broju zaposlenih pripadnika nacionalnih manjina $\mathrm{u}$ tijelima javne uprave pokazuje pad $\mathrm{u}$ broju zaposlenih, odnosno smanjenje postotnog udjela nacionalnih manji- 
na u ukupnom broju zaposlenih službenika i namještenika s dva osnovna obilježja. Prvo, riječ je o kontinuiranom smanjenju broja zaposlenih u desetogodišnjem razdoblju. Drugo, udio pripadnika nacionalnih manjina u ukupnom broju zaposlenih nije ni blizu razmjeran njihovu udjelu u ukupnom stanovništvu.

Drugo, i s tim u vezi, nezadovoljavajući učinci trenutačnog modela zapošljavanja nacionalnih manjina u javnoj upravi trebali bi potaknuti donošenje dodatnih mjera zapošljavanja koje mogu biti komplementarne primjeni ciljeva zapošljavanja kao jedinoj i isključivoj mjeri posebnih oblika zapošljavanja manjina u Hrvatskoj. U ovom se radu, na temelju provedene analize u odabranim zemljama (Vukojičić Tomić, 2017), izdvajaju najčešći oblici posebnih oblika zapošljavanja manjina koji mogu pridonijeti željenoj zastupljenosti nacionalnih manjina u upravnim organizacijama (problem diskriminacije i nejednakosti) te istodobno većoj uspješnosti organizacija putem upravljanja različitošću. To primjerice mogu biti dodatne mjere kao što su poticanje zapošljavanja, promidžbene kampanje i ciljano oglašavanje.

Treći se problem tiče opsega tijela koja imaju obvezu davanja prednosti pri zapošljavanju nacionalnim manjinama. Naime na donošenje posebnih mjera zapošljavanja u najvećoj mjeri utječu sljedeći faktori. Prvi je usklađivanje s europskom pravnom stečevinom i u manjoj mjeri međunarodnim standardima, a drugi zaštita društveno-simboličkih ciljeva koji proizlaze iz društveno prihvaćenih vrijednosti zaštite temeljnih, ali i posebnih prava skupina građana koji se nalaze u nepovoljnom ili nejednakom položaju. Njima se primarno želi poboljšati položaj manjina, pa se može reći da su afirmativnoga karaktera. Dodatno, pravo nacionalnih manjina na zapošljavanje $u$ javnoj upravi propisuje se kao pravo na razmjernu zastupljenost njihovu udjelu u ukupnom stanovništvu. Istovremeno je krug tijela javne uprave za koja se propisuje obveza zapošljavanja puno uži nego što je to slučaj s drugim društvenim skupinama koje ostvaruju pravo prednosti pri zapošljavanju, točnije osoba s invaliditetom i braniteljima. Naime nacionalnim manjinama osigurava se zastupljenost ostvarenjem prava na prednost pri zapošljavanju u tijelima državne uprave, pravosudnim tijelima i upravnim tijelima jedinica lokalne i područne (regionalne) samouprave. Opseg tijela koja imaju obvezu zapošljavanja branitelja i obvezu kvotnog zapošljavanja osoba s invaliditetom proteže se na čitavi javni sektor: tijela državne uprave, tijela sudbene vlasti, tijela državne vlasti i druga državna tijela, tijela jedinica lokalne i područne (regionalne) samouprave, javne službe, javne ustanove, izvanproračunske i proračunske fondove, pravne osobe u vlasništvu ili u pretežitom vlasništvu Republike Hrvatske, pravne osobe u 
vlasništvu ili pretežitom vlasništvu jedinica lokalne i područne (regionalne) samouprave te pravne osobe s javnim ovlastima. Iz perspektive ciljeva koji se žele postići zapošljavanjem nacionalnih manjina, postavlja se pitanje zašto je krug tijela koja su im obvezna dati prednost pri zapošljavanju bitno uži. Tome u prilog govore i podaci o zapošljavanju nacionalnih manjina $u$ javnoj upravi koji pokazuju da se njihov broj iz godine u godinu smanjuje. Zbog toga bi, na temelju provedene analize, prijedlog bio proširenje opsega tijela javne uprave (javnog sektora) koja imaju obvezu zapošljavanja i usklađivanje s propisima koji reguliraju posebne oblike zapošljavanja osoba s invaliditetom i branitelja.

\section{LITERATURA}

Andersen, M. L. i Taylor, H. F. (2008). Sociology: Understanding a Diverse Society (Fourt Edition). Belmont: Thomson Wadsworth.

Arlović, M. (2015). Pravo nacionalnih manjina u Republici Hrvatskoj. Zagreb: Novi informator.

Henderson, G. i Olasiji, T. (1995). Migrants, Immigrants and Slaves: Racial and Ethnic Groups in America. Lanham: University Press of America, Inc.

Guy, M. E., i Newman, M. A. (2005). Valuing Diversity: The Changing Workplace, u: S. E. Condrey (ur.). Handbook of Human Resource Management in Government. San Francisco: Jossey-Bass A Willey Imprint, 143-164.

Marčetić, G. (2007). Upravljanje ljudskim potencijalima u javnoj upravi. Zagreb: Suvremena javna uprava.

Meier K. J., Wrinkle, R. D. i Polinard, J. L. (1999). Representative Bureaucracy and Distributional Equity: Addressing the Hard Question, The Journal of Politics, 61 (4): 1025-1039, doi: https://doi.org/10.2307/2647552

Frederickson, H. G. (2010). Social Equity and Public Administration: Origins, Developments, and Applications. Armonk - London: M. E. Sharpe.

Mesić, M. (2006). Multikulturalizam: Društveni i teorijski izazovi. Zagreb: Školska knjiga.

Mesić, M. (2013). Pojam nacionalnih manjina i njihovo političko predstavljanje: slučaj Hrvatske, Politička misao, 50 (4): 107-131.

Omejec, J. (2000). Uloga lokalne samouprave u multikulturalnim pitanjima i međuetničkim odnosima u Republici Hrvatskoj, Hrvatska $i$ komparativna javna uprava, 2 (4): 639-695.

Peters, B. G., Schröter, E. i von Maravić, P. (2013). Representative bureaucracy: concept, driving forces, strategies, u: P. von Maravić, B. G. Peters i E. Schröter (ur.). Representative Bureaucracy in Action: Country Profiles from the Americas, Europe, Africa and Asia. Cheltenham: Edward Elgar Publishing Limited, 1-18, doi: http://dx.doi.org /10.4337/9780857935991.00005 
Petričušić, A. i Mikić, Lj. (2014). Kvaka 22 iz Poglavlja 23: Propust politike uvjetovanja u pogledu osiguranja zastupljenosti pripadnika nacionalnih manjina $u$ tijelima javne vlasti, Hrvatska i komparativna javna uprava, 13 (4): 1215-1248.

Riccucci, N. M. (2005). A practical guide to affirmative action, u: S. E. Condrey (ur.). Handbook of Human Resource Management in Government. San Francisco: Jossey-Bass A Willey Imprint, 403-423.

Smerdel, B. (2013). Ustavno uređenje europske Hrvatske. Zagreb: Narodne novine.

Tatalović, S. (1997). Manjinski narodi i manjine. Zagreb: Prosvjeta.

Vlada Republike Hrvatske, Ured za nacionalne manjine (2008). Izvješće o provođenju Ustavnog zakona o pravima nacionalnih manjina i utrošku sredstava osiguranih u državnom proračunu Republike Hrvatske za 2007. godinu za potrebe nacionalnih manjina, Nacrt.

Vlada Republike Hrvatske, Ured za nacionalne manjine (2009). Izvješće o provođenju Ustavnog zakona o pravima nacionalnih manjina i utrošku sredstava osiguranih u državnom proračunu Republike Hrvatske za 2008. godinu za potrebe nacionalnih manjina, Nacrt.

Vlada Republike Hrvatske (2010). Izvješće o provođenju Ustavnog zakona o pravima nacionalnih manjina $i$ utrošku sredstava osiguranih $u$ državnom proračunu Republike Hrvatske za 2009. godinu za potrebe nacionalnih manjina.

Vlada Republike Hrvatske (2011). Izvješće o provođenju Ustavnog zakona o pravima nacionalnih manjina $i$ utrošku sredstava osiguranih u državnom proračunu Republike Hrvatske za 2010. godinu za potrebe nacionalnih manjina.

Vlada Republike Hrvatske (2012). Izvješće o provođenju Ustavnog zakona o pravima nacionalnih manjina $i$ utrošku sredstava osiguranih u državnom proračunu Republike Hrvatske za 2011. godinu za potrebe nacionalnih manjina.

Vlada Republike Hrvatske (2013). Izvješće o provođenju Ustavnog zakona o pravima nacionalnih manjina $i$ utrošku sredstava osiguranih $u$ državnom proračunu Republike Hrvatske za 2012. godinu za potrebe nacionalnih manjina.

Vlada Republike Hrvatske (2014a). Četvrto izvješće Republike Hrvatske o provođenju Okvirne konvencije za zaštitu nacionalnih manjina.

Vlada Republike Hrvatske (2014b). Izvješće o provođenju Ustavnog zakona o pravima nacionalnih manjina $i$ utrošku sredstava osiguranih $u$ državnom proračunu Republike Hrvatske za 2013. godinu za potrebe nacionalnih manjina.

Vlada Republike Hrvatske (2015). Izvješće o provođenju Ustavnog zakona o pravima nacionalnih manjina $i$ utrošku sredstava osiguranih u državnom proračunu Republike Hrvatske za 2014. godinu za potrebe nacionalnih manjina.

Vukojičić Tomić, T. (2017). Suvremeni pristupi i modeli zapošljavanja društvenih manjina u javnoj upravi, Hrvatska i komparativna javna uprava, 17 (3): 365-388.

Wirth, L. (1945). The Problem of Minority Groups, u: R. Linton (ur.). The Science of Man in the World Crisis. New York: Columbia University Press 347-372.

\section{IZVORI}

Popis stanovništva, kućanstava i stanova 2011. godine, Državni zavod za statistiku, Zagreb, http://www.dzs.hr.

Popis stanovništva, kućanstava i stanova 2001. godine, Državni zavod za statistiku, Zagreb, http://www.dzs.hr. 
Popis stanovništva, kućanstava i stanova 2011., Stanovništvo prema državljanstou, narodnosti, vjeri i materinskom jeziku, Statističko izvješće Državnog zavoda za statistiku br. 1469, Državni zavod za statistiku, Zagreb, 2013.

\section{PRAVNI IZVORI}

Council od Europe, Parliamentary Assembly, Additional protocol on the rights of minorities to the European Convention on Human Rights, Recommendation No. 1201, 1 February 1993 (22nd Sitting).

Odluka i rješenje Ustavnog suda Republike Hrvatske, U-I-732/1998, 12. travnja 2001., Narodne novine, 36/2001.

Konačni prijedlog Ustavnog zakona o pravima nacionalnih manjina, P. Z. 536 iz prosinca 2002. (dobiveno temeljem Zahtjeva za pravo na pristup informacijama od Službe za medije Hrvatskog sabora).

Odluka o zabrani novog zapošljavanja državnih službenika i namještenika u tijelima državne uprave, stručnim službama i uredima Vlade Republike Hrvatske, Narodne novine, 153/09, 114/14, 70/116.

Prijedlog Ustavnog zakona o ljudskim pravima i slobodama i o pravima etničkih i nacionalnih zajednica ili manjina u Republici Hrvatskoj, P. Z. 44 iz svibnja 2000. (dobiveno temeljem Zahtjeva za pravo na pristup informacijama od Službe za medije Hrvatskog sabora).

Ustavni zakon o ljudskim pravima i slobodama i o pravima etničkih i nacionalnih zajednica ili manjina u Republici Hrvatskoj, Narodne novine, 56/91, 27/92, 34/92, 51/00, 105/00-pročišćeni tekst.

Ustavni zakon o pravima nacionalnih manjina, Narodne novine, 155/02, 47/10, 80/10, 93/11.

Ustavni zakon o privremenom neprimjenjivanju pojedinih odredbi Ustavnog zakona o ljudskim pravima i slobodama i o pravima etničkih i nacionalnih zajednica ili manjina u Republici Hrvatskoj, Narodne novine, 68/95.

Zakon o državnim službenicima, Narodne novine, 92/05, 142/06, 77/07, 107/07, 27/08, 34/11, 49/11, 150/11, 34/12, 49/12, 37/13, 38/13, 01/15, 138/15.

Zakon o lokalnoj i područnoj (regionalnoj) samoupravi, Narodne novine, 33/01, 60/01-vjerodostojno tumačenje, 106/03-odluka o nedavanju vjerodostojnog tumačenja, 129/05, 109/07, 125/08, 36/09, 150/11, 144/12, 19/13-pročišćeni tekst, 137/15.

Zakon o potvrđivanju Okvirne konvencije za zaštitu nacionalnih manjina, Narodne novine - MU 14/1997.

Zakon o sustavu državne uprave, Narodne novine, 75/93, 48/99, 15/00, 127/00-vjerodostojno tumačenje, 59/01, 190-03-pročišćeni tekst, 199/03, 79/07.

Zakon o suzbijanju diskriminacije, Narodne novine, 85/08, 112/12. 


\title{
Representation of National Minorities in the Croatian Public Administration: Effectiveness Assessment of Special Employment Measures
}

\author{
Tijana Vukojičić Tomić
}

\section{SUMMARY}

The aim of this paper is to examine the current model of employment of national minorities in the Croatian public administration. The author is focussed on the influence of normative measures applicable to the special forms of national minorities' employment in the Croatian public administration on the de facto employment status of national minorities. For that purpose, a review and analysis of the Croatian legislation in the field of employment of national minorities in public administration was first carried out with regard to the timeline of the adoption of regulations and provisions regulating special forms of employment. Subsequently, the results of the analysis are presented. After that, the data on the employment of national minorities in the public administration bodies for the 2006-2015 period were examined taking into consideration the number of persons belonging to national minorities employed in organisations and their share in the total number of civil servants employed and employees in general. Based on this, consideration is given to the adequacy of the existing employment model and the need for its change, i.e. the introduction of new / additional employment measures that should contribute to the equitable representation of national minorities in relation to their share in the population.

First of all, this paper provides a short overview of the 'national minority' concept, pointing to the fact that there is no unified, universally accepted definition of the term. The Croatian legislation provides for the definition of national minorities and guarantees their equality with the citizens of Croatian nationality. This chapter also deals with the changes relating to the ethnic structure of Croatian society. For that purpose, indexes of change have been calculated on the basis of census data. In the period from 1991 to 2011, the share of persons of Croatian nationality grew by $3.7 \%$ while the proportion of members of national minorities decreased by almost $60 \%$. Bearing in mind the existence of different aspects and a variety of models of selection and employment of national minorities that appear in practice, the paper briefly outlines the most frequently used measures that should contribute to the achievement of substantive equality (non-discrimination) and their integration in public organisations. Employment of national minorities in public administration assumes a special approach of selection and employment of civil servants. Changes in the socio-demographic structure of the population, combined with the more and more intensive complexity of modern societies, lead to public policies development and a whole scale of measures which endeavour to reflect the complexity of the social environment through the structure of human resources in the public administration. Additionally, special forms of national minorities' employment have been developed in the framework of the international antidiscrimination law since mid-1960s. It can be defined as the adoption of a set of special measures of employment aimed at the prevention, reduction or compensation for the disadvantage in areas of employment and integration of minorities in public organisations. Special or positive measures are, in principle, temporary because they should contribute to the improvement of 
the position of national minorities and, therefore, their duration should be determined by their functional result in response to a concrete problem. Besides, they are perceived as an exception to the general principles of non-discrimination.

In the Croatian public administration, national minorities are employed by applying special employment measures that have been introduced since the beginning of the 1990s in terms of employment obligations for public organisations. Specific regulations do not define specific measures. Their goal and scope were first defined in the Anti-Discrimination Act in 2008, and are related, among other things, to the area of employment, work and working conditions. The law defines them as an exception to the prohibition of discrimination, in accordance with the acquis communautaire. However, special employment measures were not implemented during the 1990s, that is, the suspension of these rights came about. In addition, the mechanisms for securing special employment rights were not stipulated, such as the establishment of records to enable the exercise of rights to special forms of employment to be monitored. The situation in which the laws initially introduced special public administration employment measures in for national minorities, but which were not implemented in practice, continued until the beginning of 2000. It can be concluded, therefore, that the rights of national minorities to exercise special employment measures in this period regressed. In the forthcoming period, the system was improved. Provision was made for the exercise of the right to employment priority which was to ensure the proportional representation of national minorities in the public administration bodies according to their share in the total population. Additionally, mechanisms for monitoring the exercise of the right to representation of national minorities in public administration bodies were introduced. At this stage, the impact of normative alignment with the acquis communautaire and European standards on changes in the employment system was particularly pronounced, so it can be understood as consolidation in the field of employment of national minorities.

Considering the research question of this paper, an analysis of the real effects of positive legislation on the employment of national minorities in the Croatian public administration is provided in the subsequent chapter. Minorities are provided with the right to representation in the state administration bodies, judicial bodies and administrative bodies of local and regional self-government units. Employment data in these bodies have been recorded since 2006. The analysis of the data on the number of persons employed in the state administration bodies belonging to national minorities shows a decrease in the number of employees, i.e. a reduction of the percentage of national minorities in the total number of employees with two basic characteristics. First, the continuous decline in the number of employees over a ten-year period is observed. Second, the share of members of national minorities in the total number of employees is not nearly proportional to their share in the total population. When it comes to the units of local and regional self-government, similar results are observed. During the period under review, there has been a steady decline in the number of minority employees and employees in general, while the share of minority employees in the total number of employees continues to decline. At the same time, the number of units that are required to ensure the representation of members of national minorities in their governing bodies is reduced.

The analysis indicates problems in implementing special measures for the employment of national minorities in the Croatian public administration. Based on this, some conclusions and recommendations are presented in the paper. The first recommendation relates to the establishment of a reliable instrument for monitoring, ana- 
lysing and evaluating measures that are being implemented, as such does not exist in Croatia. This is especially important because the existing model does not lead to satisfactory outcomes. Second, and in this connection, the unsatisfactory effects of the current model of employment of national minorities in public administration should encourage the adoption of additional employment measures that may be complementary to the employment objectives as the sole and exclusive measure of special forms of minority employment in Croatia. For example, there may be additional measures such as encouraging employment, promotional campaigns, and targeted advertising. Finally, given the fact that the right of national minorities to employment in public administration is stipulated as a right to proportional representation of their share in the total population, which cannot be achieved by the existing measures, it is necessary to consider extending the scope of the bodies obligated to ensure employment priority to members of national minorities in the entire public sector.

KEY WORDS: national minorities, employment, special employment measures, public administration, Croatia 
